\title{
TECTONICS AND PETROLOGY OF THE PETROVO-HNUTOVIAN ORE CLUSTER OF THE NEAR-AZOVIAN MEGABLOCK OF THE UKRAINIAN SHIELD
}

\author{
N.N. Shatalov \\ (Recommended by doctor of geological-mineralogical sciences L.S. Galetsky)
}

Institute of Geological Sciences of NAS of Ukraine, Kiev, Ukraine, E-mail: geoj@bigmir.net Doctor of geological sciences, senior scientific worker.

The results of the investigations for the large structural Petrovo-Hnutivian ore knot within the NearAzovian megablock of the Ukrainian Shield are considered. The features of fault-block tectonics and its influence on the forming ore knot are defined. The Kalmius', Oktiabrsk's and other fault zones of the orthogonal and diagonal systems and their significance in the localization of metasomatites and exceptional ore-bearing fluorite-parisite rare-earth dyke are characterized. The mineral composition of dyke is analyzed.

Key words: ore-bearing fluorite-parisite rare-earth dyke, ore knot are defined, Near-Azovian megablock, Ukrainian shield.

\section{TЕКТОНІКА I ПЕТРОАОГІЯ ПЕТРОВО-ГНУТОВСЬКОГО РУАНОГО ВУЗАА ПРИАЗОВСЬКОГО МЕГАБАОКА УКРАЇНСЬКОГО ЩИТА}

\author{
М.М. Шаталов \\ (Рекомендовано д-ром геол.-мінерал. наук Л.С. Галецьким)
}

Інститут геологічних наук НАН України, Київ, Україна, E-mail: geoj@bigmir.net Доктор геологічних наук, старший науковий співробітник.

\begin{abstract}
Наведено результати досліджень великого структурного Петрово-Гнутовського рудного вузла в межах Приазовського мегаблока Українського щита. Визначено закономірності розломноблокової тектоніки та ї̈ роль у формуванні рудного вузла. Охарактеризовано Кальміуську, Октябрську та інші розломні зони ортогональної та діагональної систем. Показано їх значення в локалізації метасоматитів і унікальної рудоносної флюорит-паризитової рідкісноземельної дайки. Досліджено мінеральний склад дайки.

Ключові слова: рудоносна флюорит-паризитова рідкісноземельна дайка, рудний вузол, Приазовський мегаблок, Український щит.
\end{abstract}

\section{ТЕКТОНИКА И ПЕТРОАОГИЯ ПЕТРОВО-ГНУТОВСКОГО РУАНОГО УЗАА ПРИАЗОВСКОГО МЕГАБАОКА УКРАИНСКОГО ЩИТА}

\author{
Н.Н. Шаталов \\ (Рекомендовано д-ром геол.-минерал. наук Л.С. Галецким)
}

Институт геологических наук НАН Украины, Киев, Украина, E-mail: geoj@bigmir.net Доктор геологических наук, старший научный сотрудник.

Приведены результаты исследования крупного структурного Петрово-Гнутовского узла в пределах Приазовского мегаблока Украинского щита. Определены закономерности разломноблоковой тектоники и ее роль в формировании рудного узла. Охарактеризованы Кальмиусская, Октябрьская и другие разломные зоны ортогональной и диагональной систем. Показано их значение в локализации метасоматитов и уникальной рудоносной флюорит-паризитовой редкоземельной дайки. Исследован минеральный состав дайки.

Ключевые слова: рудоносная флюорит-паризитовая редкоземельная дайка, рудный узел, Приазовский мегаблок, Украинский щит.

๑) N.N. Shatalov, 2015 


\section{Introduction}

In the last three decades a lot of ore occurrences and large rare metal - rare-earth element deposits are discovered within the NearAzovian megablock of the Ukrainian Shield (USh) [Быстревская, Шаталов, 1980]. Hence this megablock is considered as one of the promising rare metal - rare-earth element orebearing provinces of the USh. The Petrovo-Hnutovian fluorspar - rare-earth element deposit was among the first to discover here. It is located in the picturesque place of the Kalmius River valley, $20 \mathrm{~km}$ to the north of Mariupol City. The Petrovo-Hnutovian ore cluster includes the unique deposit having the same name.

\section{The structure and morphology of the ore body}

The ore body crops out in the rocky bluff of the left Kalmius River slope between Petrovskoie and Hnutovo villages. Early the ore body was considered as fluorspar - carbonate vein of the hydrothermal genesis [Кузьменко, 1940; Кузьменко, 1946]. Later the detection of the specific composition and high temperature constitutions in the main vein enable this vein to consider as a deep and hypabyssal carbonatite dyke [Кривдик, Ткачук, 1990; Марченко и др., 1980; Фор, Пауэлл, 1974; Шаталов, 1986]. The steeply dipping fluorspar-carbonate (with a parasite) dyke at the thickness of 0.3 to $3 \mathrm{~m}$ were tracked laterally to more $1 \mathrm{~km}$ and to a depth of $150 \mathrm{~m}$ by the tranches, exploring shafts, boreholes, and career-shaped ditch (Fig. 1). The dramatic variations of thickness and the swells along the strike form frequently the misshapen dyke. This dyke is north-east trending (NE 25-30 $)$ and northwest dipping at $75-80^{\circ}$. The dyke is composed by the coarse-grained and block massive aggregates of purple fluorite, pink fluorine-carbonates, and multicolored calcite. The country rock of main carbonatite dyke (fluorspar - rare earth deposit) is granosyenites from the Kalmius massif. They are cataclased and metasomatically altered along the strike and in depth. As a matter of fact the dyke cuts across the zone of fenitizated pyroxene- hornblend granosyenites.

In the dyke selvages the carbonates are presented by the porcellaneous brown and gray crystals, as well as coarse-grained aggregates of white and pink calcite in its central part. Carbonates were analyzed and their compositions include magnesium, strontium, manganese, and $\mathrm{Ce}$ - based lanthanides that is characterized for carbonates of alkali rock and carbonatites. Sulfides of cooper, zinc, and lead are present as impregnation. Secondary carbonates are represented by fluocerite, barite, hematite, smithsonite, etc. At the later stage the process of alkali-silic metasomatose for fluorspar-carbonate dyke rock has been carried out forming massive segregations and veinlets of chalcedony with the inclusions of fresh biotite. Chalcedonotites are high developed along carbonatite dyke strike and in the neighborhood of the ancillary smaller veins, which are similar in composition [Марченко, 1965; Марченко и др., 1980]. The contact zones of ore-bearing dyke with country rocks are quite sharp and often tortuous. At the orebearing dyke contact the narrow strip of the crushed feldspathic rock cemented by calcite, fluorspar, and aegirine is shown up. The fluorspar-carbonate-aegirine zone at the thickness of $5 \mathrm{~cm}$ has been found in the hanging wall of dyke at contact zone with country rock. Parallelly to carbonatite dyke in its hanging wall with the host diallage-hornblende granosyenites there are dense net of small veinlets in north-east strike represented by aegerine, alkali amphibole, fluorspar, and calcite [Кузьменко, 1946]. A lot of small veinlets are here stretched in north-east direction $\left(\mathrm{NE} 25^{\circ}\right)$ at the north-west dip (NW 75-80 $)$. The host granites and syenites are also enriched by aegirine and alkali amphibole along the mentioned veinlets of fluorspar, calcite, and aegirine. Alkali amphibole and aegirine intrude into the country rocks as the crystal accumulation and simple needles penetrated densely into feldspars replacing them often. They form the tortuous bands and fill up the small fissures. Granites and syenites of the Petrovo-Hnutovian ore dyke at contact zone turn into the typical cataclasite with segregation of alkali amphibole and aegerine [Кузьменко, 1940; Кузьменко, 1946; Марченко и др., 1980]. For the several plots of the described structural junction, where the hanging dyke wall hosts granosyenites at the thickness of a few meters, they are converted to apatite - sphene - albite - arfvedsonite aegerine fenites with accessory ilmenite, chevkini-te, zircon, magnetite, and hematite [Марченко, 1965; Марченко и др., 1980]. 


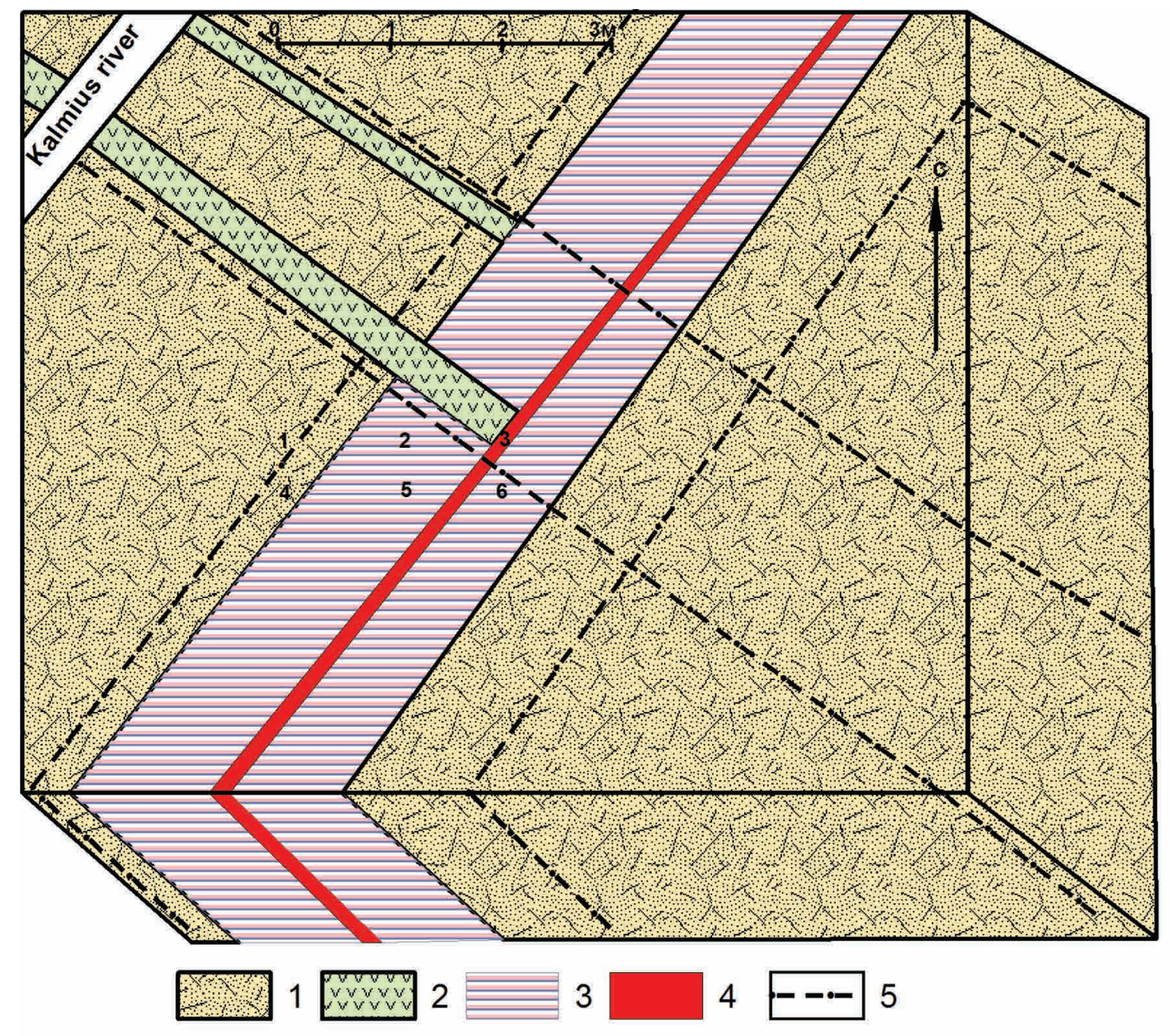

Fig. 1. Geological-structural scheme (block-pattern) for one site of the Petrovo-Hnutovian fluorite-rare earth deposit

1 - granites and syenites altered metasomatically; 2 - Paleozoic lamprophyre dykes; 3 - Precambrian ore-bearing fluorite-carbonate dyke; 4 - little mylonite zone in the ore-bearing dyke; 5 - disjunctive dislocations

The bottom dyke wall hosts the high fenitizing syenites. The fenitization zone is about $30 \mathrm{~m}$. Fenites are represented by albitized and quartz y feldspar rocks. Here chalcedone and aegerine occur as the veinlets. Fenites are cut across by the numerous veinlets of niobiumbearing sphene, fluorspar, and carbonates. Sphene forms the aggregates of large crystals and numerous veinlets cutting phenites. A mineral includes the microelements as the follows: $\mathrm{Na}_{2} \mathrm{O}(0.26 \%), \mathrm{Nb}_{2} \mathrm{O}_{5}(0.35 \%)$, SrO $(0.02 \%)$, $\mathrm{Tr}_{2} \mathrm{O}_{3}(1.28 \%)$, the cerium group ones. This composition is usual for sphenes from alkaline rocks [Кривдик, Ткачук, 1990; Марченко, 1965]. The outcrop of feldspar-ilmenite peg- matoid rocks with large blocky structure is evidenced along the strike of fenitic country rock zone with the central dyke of carbonatites. Ilmenite crystals here reach to $10 \mathrm{~kg}$ in weight. Ilmenite contains $\mathrm{TiO}_{2}$ (51.31\%), $\mathrm{MnO}$ (6.06\%), $\mathrm{MgO}$ (1.99\%). Marchenko E.Ya. et al. [Mapченко и др., 1980] consider ilmenite-bearing pegmatoid rocks developed at the southnorthern extension of carbonatite dyke as the earliest alkaline magmatic formations. Syenitepegmatites are enriched by titanium and both ilmenite from these rocks and sphene from fenites at the dyke contact have the similar microelement composition. 


\section{Petrologic composition of ore dyke}

The petrologic analysis shows that the orebearing dyke is primarily composed of carbonate (calcite and parisite), fluorspar, quartz, and chalcedony. Ore minerals are presented by galena, sphalerite, copper pyrite, pyrite, and argentite. The secondary minerals are limonite, white lead ore, covellite. Main minerals are calcite, fluorspar, and parasite, which are closely accreted with each other into massive grained aggregates. Parasite and fluorspar are segregated in the pockets and bands stretching along the dyke strike [Кузьменко, 1940; Кузьменко, 1946; Марченко и др., 1980].

$\mathrm{C}$ a I c i t e. It is a main crystal of carbonates. In rock there are two generations of calcite. The earlier calcite forms the large and fine grains. It has the irregular form, excellent pronounced cleavage and twinning along the rhombohedron plate. The grain size is to $3 \mathrm{~cm}$. Colors of calcite are white, pink, and pale pink. Pink color is due to the presence of isomorphous impurities of rare earths in a mineral, contents of which are increased with coloration intensity rising from $0.88 \%$ in white variety to $3 \%$ in pale pink one and to $7.28 \%$ in deep pink one; calcite of pink shades is primary occurred on the edges of parasite pockets [Кузьменко, 1946]. Calcite of late generation is colorless, but it becomes brownish near its surface. It forms fine perfectly transparent grains and aggregates filling the network of thin veinlets through the fissures.

$\mathrm{P}$ a r i s i t e. It is raspberry - pink with the different hues. Its crystals are grown together calcite and fluorspar ones differentiating often into single pockets and bands. The hardness is about 4 , the specific gravity is 4.36 , and the grain size is to $2 \mathrm{~mm}$. Its crystals are colorless or grayish in transmitted light under the microscope. They are optically uniaxial, positive crystals. The interference colors are bright, i.e. pink, green, dark blue, and purple. Cleavage is obscure. The reflective indices are for $n_{g}=1.755$ and $n_{p}=1.67$. The numerous parasite grains are fissured. This induces the parasite grain browning that is expressed in the appearance of straight parallel bands. The grains are fine with prismatic habit. The clustered aggregates are fine - and - medium grained. In the parasite pockets calcite occurs ever forming the intimate granular twinning. Against calcite background parasite is observed as fine dispersed grains and spots, as well as the veinlets with the inclusion of fluorspar aggregates.

$\mathrm{F} \mathrm{I} \mathrm{u} \mathrm{o} \mathrm{r}$ i t e forms the pockets, lenses, bands, dispersed aggregates and grains within carbonates. Fluorite is cemented by calcite and chalcedony along the cracks. The colors of the fluorite are green and purple with many shades. The dark purple fluorite is dominant. The colored fluorite specimen lightens up in the daylight. Fluorite forms the large grains of well-marked octahedral cleavage, perfect on $\{111\}$. Under the microscope in transmitted light fluorite mineral is colorless, slightly pink or lilac. It may contain the fine grains of quartz and carbonates as the inclusions.

$\mathrm{Q} u$ a $\mathrm{r} \mathrm{t} \mathrm{z}$ plays a subordinate role in rock and is detected only under the microscope. There are two quartz generations. The earlier one as inclusions of fine grains and regular prismatic crystals occurs in calcite, parasite and occasionally fluorite. The later quartz fills up the microfissures in rock.

$\mathrm{C} h$ al c e d o $\mathrm{n}$ y forms the pockety segregations replacing carbonates and fluorite. Chalcedony in rock is observed as a net of thin veinlets.

Ore minerals. As far as the primary minerals galena and sphalerite play a prominent role while pyrite and chalcopyrite are subordinate. The secondary minerals consist of malachite, argentite, covelline, chrysocolla, cerussite, limonite, and pyrolusite. The chemical analyses of parasite, carbonates, and fluorcarbonates from the Petrovo-Hnutovian dyke as well as the contents and compositions of rare earth elements in the minerals and country rocks are seen in Table 1 and Table 2, respectively. The geochemical study of monomineral samples of calcite, parasite, and fluorite has shown a number of features in the distribution of elements- impurities, rare earth elements and rare ones such as strontium, yttrium, lanthanum, cerium etc. Thus parasite contains $55.73 \%$ rare earth elements (average of three samples). Rare earths composition in parasite is entirely ceric $\left(\mathrm{TR}_{\mathrm{Ce}}: \mathrm{TR}_{\mathrm{Y}}=82\right)$. Cerium accounts for a half of the total content of the rare earth elements. In calcite relative to parasite significance of rare earth elements from yttrium group is increasing $\left(\mathrm{TR}_{\mathrm{Ce}}: \mathrm{TR}_{\mathrm{Y}}=6.7\right)$ and rare earths content in calcite reaches $0.7 \%$ [Куц, 1971]. The high contents of rare elements 
are also observed in fluorspars from the Petrovo-Hnutovian deposit, i.e. $0 / 12 \%$ at the $\mathrm{TR}_{\mathrm{Ce}} / \mathrm{TR}_{\mathrm{Y}}$ ratio of 0.26 . Attention should be given to the high strontium concentration in calcite $(1179 \mathrm{~g} / \mathrm{t})$ and fluorspar $(838 \mathrm{~g} / \mathrm{t})$ that is typical for the productive stage of ore formation [Панов и др., 1980; Панов, Панов, 2000].

\section{An age}

Time of intruding ore-bearing Petrovo-Hnutovian carbonatite dyke is determined using geological-structural and isotopic datasets. The dyke cuts through gneissic-migmatite thickness and proterozoic pyroxene - hornblende granosyenites, in turn, it is cutting by the younger dykes of lamprophyres, diabases, and orthophyres [Панов, Коньков, 1966; Панов и др.,

Table 1. Chemical composition (\%) of carbonates, fluorine-carbonates, and parasite from the Petrovo-Hnutovian deposit

\begin{tabular}{|l|c|c|c|c|}
\hline Component & 1 & 2 & 3 & 4 \\
\hline $\mathrm{SiO}_{2}$ & 1,84 & 1,21 & 3,00 & 1,41 \\
\hline $\mathrm{TiO}_{2}$ & 0,06 & 0,07 & 0,09 & 0,04 \\
\hline $\mathrm{Al}_{2} \mathrm{O}_{3}$ & 0,10 & - & 0,37 & 0,56 \\
\hline $\mathrm{Fe}_{2} \mathrm{O}_{3}$ & 0,67 & 1,00 & 0,95 & 1,38 \\
\hline $\mathrm{FeO}$ & 0,10 & 0,09 & 0,14 & - \\
\hline $\mathrm{CaO}$ & 51,82 & 1,46 & 22,07 & 13,42 \\
\hline $\mathrm{MnO}$ & 2,86 & 0,18 & 0,32 & - \\
\hline $\mathrm{MgO}$ & 0,88 & 0,10 & 0,21 & 0,97 \\
\hline $\mathrm{K}_{2} \mathrm{O}$ & 0,05 & - & 0,10 & - \\
\hline $\mathrm{Na}_{2} \mathrm{O}$ & 0,02 & - & 0,21 & - \\
\hline $\mathrm{CO}_{2}$ & 39,55 & 24,68 & 29,01 & 23,36 \\
\hline $\mathrm{P}_{2} \mathrm{O}_{5}$ & 0,03 & 0,03 & - & - \\
\hline $\mathrm{H}_{2} \mathrm{O}+$ & 1,71 & - & 0,43 & 0,09 \\
\hline $\mathrm{H}_{2} \mathrm{O}-$ & 0,15 & 0,08 & 0,17 & - \\
\hline $\mathrm{F}$ & 0,28 & 5,50 & 3,70 & 5,57 \\
\hline $\mathrm{SrO}$ & 0,20 & 0,30 & - & - \\
\hline $\mathrm{TR}_{2} \mathrm{O}_{3}$ & - & 54,44 & - & 55,46 \\
\hline
\end{tabular}

Note: 1 - carbonates, the mean of 4 analyses [Mapченко и др., 1980]; 2 - fluorine-carbonates, the mean of 3 analyses [Марченко и др., 1980]; 3 - parasite, the mean of 2 analyses [Кузьменко, 1946]; 4 - parasite, the mean of 2 analyses [Куц, 1971].
1980]. The $U-\mathrm{Pb}$ ratio gives the age of galena from proteriozoic dyke dating as 2.1 to $1.92 \mathrm{Byr}$ [Марченко и др., 1980; Панов, Коньков, 1966]. Some age overestimates for galena can manifest the assimilation of the ancient lead from the country rocks of substratum as are assumed [Марченко и др., 1980] that indicates the abyssal origin of dyke rocks. Isotopic dating of galena from aegirine - fluorite - riebeckite metasomatite of the Petrovo-Hnutovian deposit gives 2 Byr [Елисеев и др., 1965]. Isotopic dating of hornblende from the veinlets adjacent to the dyke yielded 1.5 Byr [Куц, 1971]. Therefore the structural, geological , and isotopic dating data give evidence the vicinity in the formations of dyke rocks and granosyenite massifs of the Near-Azovian area (1.9-1.8 Byr).

Table 2. Content ( $\left.n \cdot 10^{-4} \%\right)$ and composition for rare earth elements in minerals and granosyenites from the Petrovo-Hnutovian deposit [Куц, 1971; Панов и др., 1980]

\begin{tabular}{|c|c|c|c|c|c|}
\hline $\begin{array}{l}\frac{\vec{D}}{\Phi} \\
\frac{\vec{d}}{\omega}\end{array}$ & 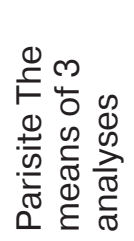 & $\frac{\stackrel{0}{\frac{D}{0}}}{\frac{\pi}{\widetilde{N}}}$ & 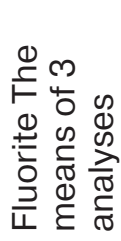 & 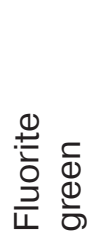 & 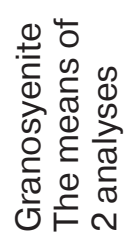 \\
\hline $\mathrm{La}$ & 28,6 & 23,9 & 10,5 & 33,0 & 9,3 \\
\hline $\mathrm{Ce}$ & 48,0 & 40,0 & 19,5 & 84,0 & 41,0 \\
\hline $\mathrm{Pr}$ & 4,9 & 5,4 & 2,4 & - & 7,7 \\
\hline $\mathrm{Nd}$ & 15,9 & 14,0 & 7,5 & 97,0 & 19,4 \\
\hline $\mathrm{Sm}$ & 1,3 & 1,3 & 1,6 & 31,0 & 3,0 \\
\hline $\mathrm{Eu}$ & - & 0,2 & 1,9 & 6,0 & 3,1 \\
\hline $\mathrm{Gd}$ & 1,3 & 2,4 & 2,3 & - & - \\
\hline $\mathrm{Tb}$ & - & 0,1 & 0,3 & 7,9 & 0,3 \\
\hline Dy & - & 1,7 & 2,9 & 5,8 & 2,2 \\
\hline Ho & - & 0,4 & 1,1 & - & 1,0 \\
\hline $\mathrm{Er}$ & - & 0,2 & 3,3 & - & 1,0 \\
\hline $\mathrm{Tu}$ & - & 0,01 & 0,2 & - & 0,6 \\
\hline $\mathrm{Yb}$ & 0,2 & 1,5 & 2,7 & 22,0 & 1,3 \\
\hline Lu & - & 0,1 & 0,1 & 2,6 & 0,2 \\
\hline$Y$ & 1,0 & 9,0 & 44,9 & 910,0 & 10,0 \\
\hline $\mathrm{Rb}$ & - & - & - & 5,0 & - \\
\hline $\mathrm{Sr}$ & - & - & - & 838,0 & - \\
\hline
\end{tabular}




\section{Genesis}

The rare earth mineralization of the PetrovoHnutovian carbonatite dyke is characterized by certain specifity displaying its primary-mantle magmatic origin. It should be primarily pointed out the simple composition of minerals, such as carbonates (calcite and parasite) and fluorite. Since the mentioned triad belongs to the most fluorophilic elements and fluorite occurs here abundantly the mantle source must be considered as the primary origin of rare earth mineralization. In parasite of the Petrovo-Hnutovian carbonate-fluorite dyke the $\mathrm{O}^{18}$ values range from +6.4 to $10.5 \%$ o providing evidence of endogenous origin of carbonates. This is proved by isotopic carbon composition at the $\mathrm{C}^{13}$ value of -4.5 to $-8.6 \%$ [Панов, Панов, 2000]. The high temperatures and "the deep depth" of rock formation for the carbonatite dyke are proved by decrepitation data. The decrepitation curve peaks for the block fluorite and galena are indicated at $480^{\circ} \mathrm{C}$ and $460^{\circ} \mathrm{C}$, and $465^{\circ} \mathrm{C}$, respectively. This is higher than temperatures obtained by homogenization method for fluorite (the earlier generation at $395-365^{\circ} \mathrm{C}$ and $330-300^{\circ} \mathrm{C}$ and the late one at $270-245-215^{\circ} \mathrm{C}$ ). The constant peaks of decrepitation curves for pink carbonatites from the main mass of dyke are recorded at $730^{\circ} \mathrm{C}$ and $460^{\circ} \mathrm{C}$ [Марченко и др., 1980]. It is important to emphasize that the porcellaneous carbonatites from the contact layer of the dyke don't show the decrepitation effects when heated that is likely connected with the destruction of the rock inclusions due to the "quenching" process. The low temperature peaks of the decrepitation curves and the inclusions in fluorite, which is homogenized at $180-120^{\circ} \mathrm{C}$ are proved the late hydrothermal conversion of carbonatite dyke rocks as a result of alkali-silic metasomatism processes [Кузьменко, 1946; Марченко, 1965; Панов, Панов, 2000].

The high temperatures of carbonatite formation are indicative of the intensive alkaline metasomatism in the exocontacts of dyke (albitization, aegirinization, apatitization, sphenization). Fluorite, carbonates, fluorocarbonates from the groundmass are similar minerals in the formation time, crystallization of which has been proceeding from the rich alkali-carbonate melts into the steep dipping cracks of the Kalmius deep fault. Owing to the injection the dykes of carbonatites consisting the granosyenites of the Kalmius massif have undergone the high temperature metasomatic alteration conversing into fenites. The low temperature alteration (chalcedonization) is a superimposed process, which is observed at the localities where fluorite-carbonate dykes and veins are absent.

"The deep depth" of forming the PetrovoHnutovian rocks of carbonatite dyke is proved by the Sr isotopic ratio. The above mentioned data give an evidence of similarity of mineralogical and geochemical features of this dyke to carbonatites from the Mountain Pas s veined field in the Precambrian of California.

The ${ }^{87} \mathrm{Sr} /{ }^{86} \mathrm{Sr}$ ratio in carbonatites from the Mountain Pas was found to be 0.704 [Пауэлл и др., 1969], i.e. it is equal to the mean ratio value for carbonatites under study [Фор, Пауэлл, 1974] and indicates the deep source of strontium and carbonatite character of dykes.

The identity of the Petrovo-Hnutovian rocks with carbonatites is observed through their spatial and structural relationship with fenites, special mineral and microelemental composition, and high temperature for rock- and ore formation. The widespread development of fluorine-containing minerals (fluorine, fluoro-carbonates, fluocerite) and late silicification point at the hypabyssal character of dyke formation. It is known that carbonatite massifs of the profound carbonatite complexes concentrate fluorine into apatites, micas and less deep fluorine-bearing carbonatites contain own minerals such as fluorite, etc. Yet it is important to emphasized the fenite alterations of the country rocks, enrichment of fluorite and carbonates by alkali, titanium, phosphorus, selectively cerium composition of lanthanides, as well as the high temperature formation are intrinsic for the deep carbonatites rather than common fluorite veins of the hydrothermal genesis.

\section{The geological-structural position of the Petrovo-Hnutovian ore cluster}

The fluorite - rare earth ore deposit is localized within the Petrovo-Hnutovian structural joint, situated at the Near-Azovian megablock of the USh in the intersection zone of the deep faults of diagonal and orthogonal systems (Fig. 2). Furthermore in the large structural joint the numerous dykes of lamprophyres, diabases, diorite porphyrites, and orthophyres, which 
differ in composition, age, and dimensional orientation are developed [Шаталов, 1980; Шаталов, 1986]. Here the cataclasis areas, myIonitization and strong alkalization of country rocks are observed. The Kalmiuss tectonic zones is major among the diagonal faults being the ore control structure along the lateral and into the depth at a distance from Petrovskoie vil. to Hnutovo vil. Just this zone matches exactly along the strike together with the orebearing fluorite-parisite dyke injected from the Earth's interior. In just this period of evolution the fissuring and stretching of the formed, relatively thick, compact, and solid-crystalline earth crust of the Near-Azovian megablock took place. The Kalmiuss deep fault is distin- guished by remote sensing data [Быстревская, Шаталов, 1980; Быстревская, Кливаденко, 1980], it stretches in the north-eastern direction (NE 25-30') from the Black Sea (to the south of Kerch), through the Sea of Azov, the Near-Azovian megablock of the USh (the city of Mariupol and urban village of Hranitnoie) and Donbas (to east of Donetsk City) to the Voronezh crystalline massif (VCM). Its width at the different parts is 5 to $10 \mathrm{~km}$ and the length is hundreds of kilometers (Fig. 3). The described zone is characterized by the whole complex of geological and geophysical features for the deep faults as the follows: the large length, persistent stretch, it may cross up the different tectonic structures of the ancient

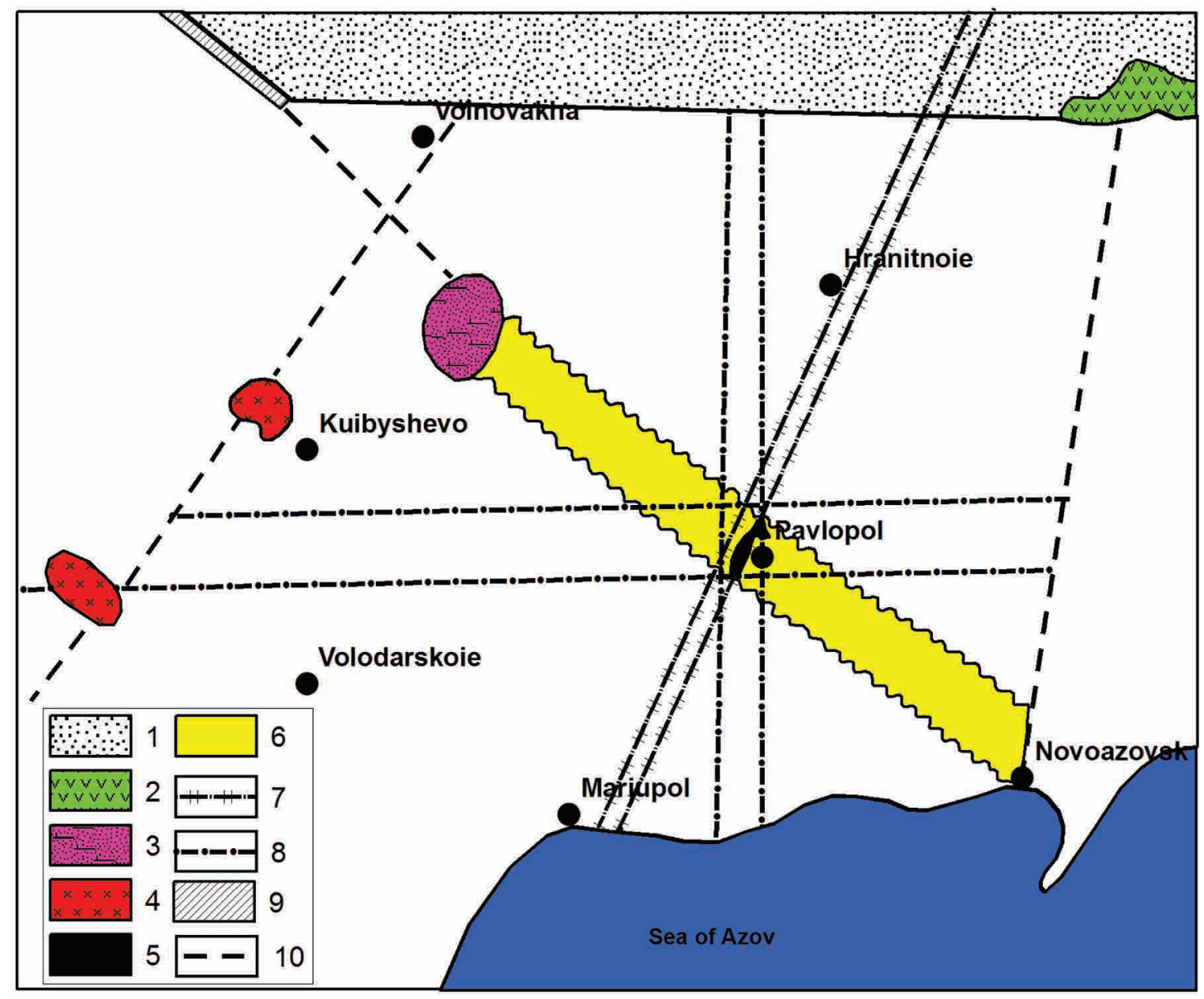

Fig. 2. The scheme of the Petrovo-Hnutovian structural junction of the Azovian area

1 - sediment-volcanogenic rocks for the junction zone between the Donbas and Near-Azovian area; 2 - Pokrovo-Kireevskaia volcanogenic structure; 3 - Oktiabrsk's alkali massif; 4 - Yekaterinovsky and Kamennye mohily granite massifs; 5 - the Petrovo-Hnutovian parisite-fluorite dyke; 6 - the boundaries of the Pavlopol-Oktiabrsk's dyke belt; 7 - Kalmius deep fault; 8 - the faults of the orthogonal system; 9 - Kryvorozhsko-Pavlopolsky fault; 10 - Hruzsko-Yelanchiksky and Donetsko-Hurzufsky fault zones 


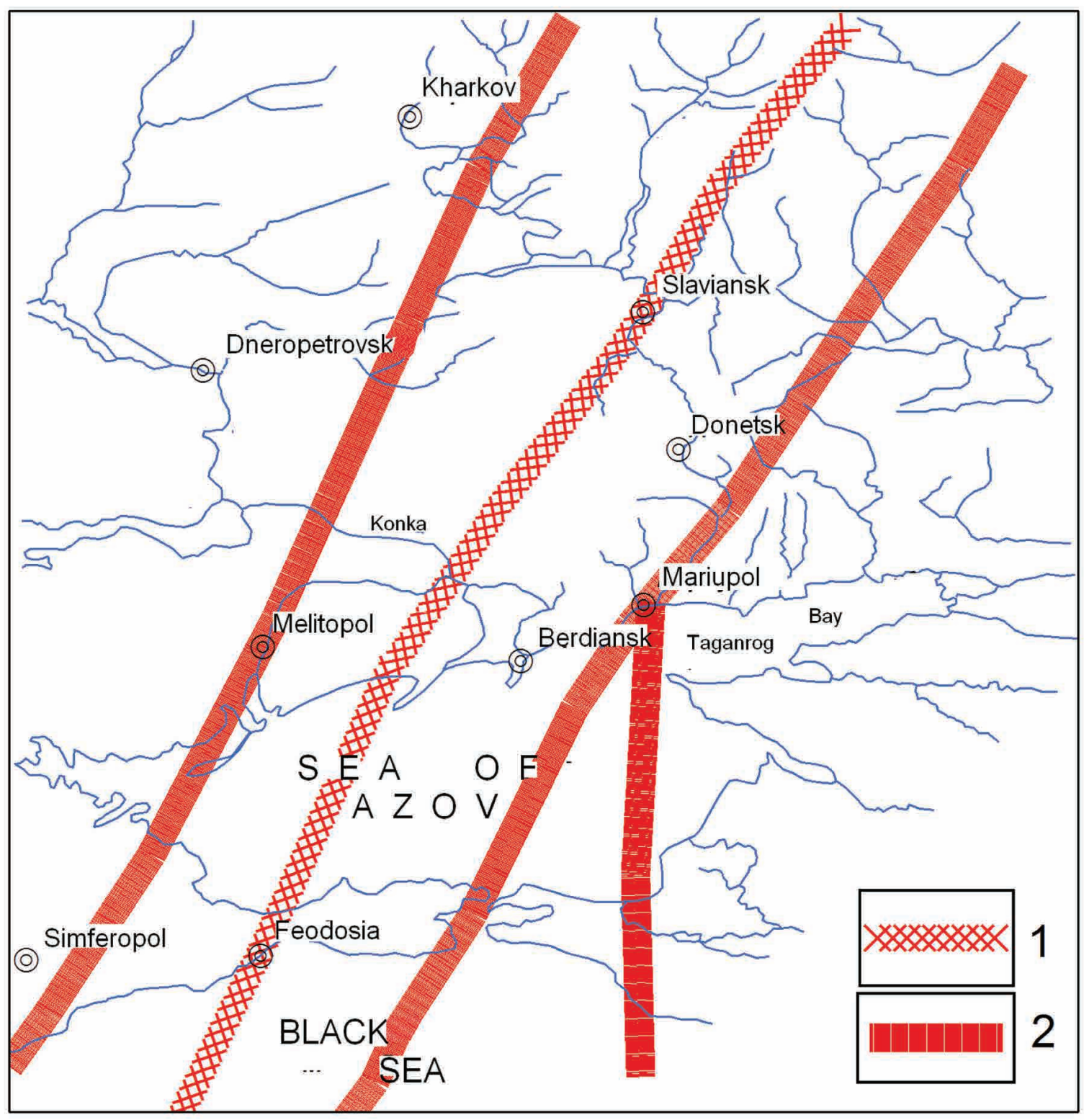

Fig. 3. Tracing scheme for the Kalmius, Feodosiisko-Slaviansky and Orekhovo-Pavlohradsky lineaments using aero- and satellite images [Быстревская, Кливаденко, 1980]

1 - Feodosiisko-Slaviansky fault; 2 - Orekhovo-Pavlohradsky and Kalmius deep faults

Eastern European Platform (VCM, Donbas, Near-Azovian megablock of the USh), The Northern Azovian Depression, Azov bar, recent Scythian Platform, and Black Sea Depression. The fault within the Near-Azovian megablock of the USh seperates the upstanding and downthrown blocks of the earth crust with the different structure and variable occurrence depth of the Moho discontinuity. Just here the fault is clearly distinguished in the gravitation fields as the steps. The study of the inner structure of the fault within the Near-Azovian megablock shows that this disjunctive dislocation is no represented a narrow linear seal, but the complex system of the various oriented short disturbances presented by the zones of foliation, breaking, mylonitization, and metasomatosis. These fine dislocations crossing each other generate the several accumulations along the river Kalmius. One of the locations with the dense network of fine dislocations stretches from Petrovskoie vil. To Hnutovo vil. and the 
second lies between Nikolaievka vil. and Pavlopol vil. As far as a kinematics the Kalmius fault is classified as the left-lateral strike-slip with the amplitude of the horizontal displacement of the walls in the first tens of kilometers [Чебаненко и др., 1991].

According to the tectonic significance, the features of geodynamics, magmatism, mineralogical and geophysical characteristics the involvement of the Oktiabrsk (Donskoy) deep fault in the formation of the very complicated Petrovo-Hnutovian structural junction was also very important. The zone of the Oktiabrsk fault is the south-eastern elongation of the Kryvorozhsko-Pavlovsk one described by Levenshtein [Левенштейн, 1959] in the region of Paleozoic sedimentary rock development of Donbas. In the whole the Oktiabrsk fault is represented as the large disjunctive dislocation (by the type of fault and strike-slip) with the deep foundation and regional significance in the structure of the Near-Azovian megablock of the USh. Owing to the study of the dykes in the region the fault was marked out by the author into the south-eastern direction to Novoazovsk city, i.e. up to the shoreline of the Sea of Azov [Шаталов, 1982; Шаталов, 1986]. In the region of the Oktiabrsk alkali massif this fault is clearly distinguished in the shifts of the Moho discontinuity, which are observed by the DSS profiles for the interval of Taganrog - Dnipropetrovsk.

The fault zone is clearly tracked by the series of hypabyssal dykes of lamprophyres, diabases, diorite porphyrites, and orthophyres into the north-eastern direction from Novoazovsk city to the Oktiabrsk alkali massif. Congestion of the dyke bodies are observed along the Kalmius River in the interval at the width of 7- 8 $\mathrm{km}$ (between the villages of Pavlopol and Nikolaevka). The outcrop of dykes occur also between Petrovo and Hnutovo villages, along the gullies of Chernechia, Verbovaia, Kalmytskaia, and Ternovaia, which are the right-bank tributaries of the river Kalmius. As a result the width of dyke swarm for the described structural junction increases to $15 \mathrm{~km}$. Across the strike of the fault zone we found at least 100 dykes among those are the dykes of sub-meridian and sub-latitudinal orientation, however the dykes of north-western direction is prevailed. The investigated dyke swarm was distinguished by the author earlier reffered to as the Pavlopol - Oktiabrsky dyke swarm [Шаталов, 1981;
Шаталов, 1986]. Within the swarm the dykes of orthophyres are quantitatively dominated. They are the youngest Paleozoic intrusions crossing the dykes of lamprophyres from the Phanerozoic and also diabases, diabase porphyrites, and lamprophyres from the Upper Proterozoic. The fragments of orthophyres observed in the boreholes southeastward from the PetrovoHnutovian structural junction occur in the relatively wide developed conglomerates of the Late Triassic age [Шаталов, 1980; Шаталов, 1986; Щербак и др., 2008]. Some individual dykes of the Pavlopol - Oktiabrsky dyke swarm may be traced along the strike up to $2 \mathrm{~km}$. Here the thickness of lamprophyres and diabases dykes and orthophyres ones is mainly to $2 \mathrm{~m}$ (sometimes $5 \mathrm{~m}$ ) and to $20 \mathrm{~m}$, respectively. The overall thickness of dykes in the structural junction is at least $500 \mathrm{~m}$. In some areas the dykes cover to $15 \%$ of the overall volume of country rocks. In addition to the dyke series the Paleozoic volcanic-plutonic structures are found in this structural junction using geophysical and geological surveys. In particular, the drilling has detected a number of volcanic structures of the central type, i.e. volcanic throats. Their size is from tens meters (the gully of Verbovaia) to 2 $\mathrm{km}$ and more (the gullies of Kichiksu and Kirilovskaia). Among the determined sub-volcanic formations the orthophyres (trachytes) are prevailed. Congestion of the poor thick dyke lamprophyre bodies (to 1-2 $\mathrm{m}$ ) of sub-latitudinal and north-western orientation is located in vicinity to the fluorspar - parasite dyke. The additional exploration of one of sites of ore-bearing carbonatite dyke revealed the character of intersection and displacement for the fragment of lamprophyre dyke cutting the near-contact fenitization zone and fluorspar - carbonatite dyke (Fig. 1). Based upon the Figure 1 the Paleozoic shift for the body of Precambrian carbonatite dyke along the fault in the north-east strike is obvious.

As far as the structural pattern of the Petrovo-Hnutovian ore cluster the fault zones of sum-meridian and sub-latitudinal orientations are subordinate. The sub-meridian jointing systems manifest here the numerous aegirine, aegirine-amphibole, and fluorsparcarbonate veins at the thickness to $2 \mathrm{~m}$, but the sub-latitudinal ones carries fenite zones and steeply dipping, poor thick (to $1 \mathrm{~m}$ ) lamprophyre dykes at the strike of $270^{\circ}$. 


\section{Conclusions}

The analysis of above studies shows that the faults of the orthogonal and diagonal systems (Kalmius and Oktiabrsk's faults) have dissected the area of the defined structural junction into the number of small wedge shaped geoblocks. As a result there are here the sites with maximal fragmentation and permeability of lithosphere that is favorable for the localization of metasomatites and ore minerals. Owing to the activation of the deep tectonic- magmatic processes within the large structural junction the smaller Petrovo-Hnutovian ore cluster was formed and the unique fluorspar parasite rare earth dyke was intruded. The above mentioned features of tectonic, magmatic, and metasomatic processes (depth, multiphase, multistage, and intensity) induced the earth crust fragmentation and high differentiation of matter, which are important for the formation of industrial concentrations of rare earth elements and fluorite within the Petrovo-

\section{References}

1. Быстревская С.С., Шаталов Н.Н. Глубинная структура земной коры по космическим изображениям (на примере Восточного Приазовья). Исследование Земли из космоса. 1980. № 5. C.10-16.

Bystrevskaja S.S., Shatalov N.N., 1980. Abyssal earth crust structure from space images (Case of the eastern Near- Azovian area). Issledovanie Zemli iz Kosmosa, № 5, p. 10-16 (in Russian).

2. Быстревская С.С., Кливаденко Л.Л. Феодосийско-Славянский линеамент. Докл. $\mathrm{AH}$ УССР. Сер. Б. 1980. № 9. С. 3-8.

Bystrevskaja S.S., Klivadenko L.L., 1980. Feodosiisko-Slaviansky lineament. Dokl. AN USSR. Ser. $B$, № 9, p. 3-8 (in Russian).

3. Галецкий Л.С. Гентгельвиновое оруденение - новый высококачественный тип бериллиевого сырья. Геология рудных месторождений. 1971. Т. 13, № 3. С. 21-30.

Galetsky L.S., 1971. Genthelvite mineralization as a new high quality type of beryllium mineral materials. Geologiya rudnykh mestorozhdeniy, vol. 13, № 3, p. 21-30 (in Russian)

4. Галецкий Л.С., Зарицкий А.И., Князев Г.И. Субграфические сподуменовые и петалит-сподуменовые пегматиты одного из докембрийских полей. Геол. журн. 1987. Т. 47, № 1 (232). C. 136-141.

Galetsky L.S., Zaritsky A.I., Kniazev G.I., 1987. Subgraphic spodumene and petalite- spodumene
Hnutovian ore cluster. Just these factors have determined the occurrence of mineralization in the conditions of intersection of the large zones of the deep faults within of those the long-term evolution of tectonic-magmatic and metasomatic processes both at great depth and subsurface parts of lithosphere are occurred. The Petrovo-Hnutovian ore cluster has to be attributed to unique rank in the own parameters of petrology and ore content as the followings: high local concentration of fluorite and rare elements as well as rather simple mineral composition of ore. Rare earth mineralization in ore composition represents mainly parasite serving as rock-forming mineral. The content of this mineral for the many similar regions of USA, Commonwealth of Independent States, Canada, Italy, Greenland, and Madagascar does not usually exceed accessory values. That is why the rare earth Petrovo-Hnutovian deposit is unique not only for Ukraine, but for the other regions of the world.

pegmetites for one of Precambrian fields. Geologicheskiy zhurnal, № 1 (232), p. 136-141 (in Russian).

5. Гурский Д.С., Чорнокур І.Г. Пержанське родовище берилію (геологія та перспективи освоєння в контексті світових і вітчизняних тенденцій розвитку мінерально-сировинної бази рідкісних металів). Мінер. ресурси України. 2009. № 4. C. 23-32.

Hursky D.S., Chornokur I.H., 2009. Perzhanske deposit of beryllium (Geology and perspectives of exploration in context of world and native tendencies of development of mineral raw materials base for rare metals). Mineralny resursy Ukrainy, № 4, p. 23-32 (in Ukrainian).

6. Гурський Д.С., Єсипчук К.Ю., Калінін В.І. Металічні корисні копалини. Київ; Львів: Центр Європи, 2005. Т. 1. 710 с.

Hursky D.S., Yesypchuk K.Yu., Kalinin V.I., 2005. Metal useful mineral. Kyiv; Lviv: Tsentr Evropy, vol. 1, 710 p. (in Ukrainian).

7. Елисеев Н.А., Кушев В.Г., Виноградов Д.П. Протерозойский интрузивный комплекс Восточного Приазовья. Москва; Ленинград: Наука, 1965. $200 \mathrm{c}$.

Yeliseev N.A., Kushev V.H., Vinogradov D.P., 1965. Proterozoic intrusive complex of the Eastern Near-Azovian area. Moskow; Leningrad: Nauka, 200 p. (in Russian). 
8. Кривдик С.Г., Ткачук В.И. Петрология щелочных пород Украинского щита. Киев: Наук. думка, 1990. 408 с.

Krivdik S.H., Tkachuk V. I., 1990. Petrology of alkali rocks of the Ukrainian Shield. Kiev: Naukova Dumka, 408 p. (in Russian).

9. Кузьменко В.І. Рідкісні землі в ПетровоГнутовській флюорито-карбонатній жилі в Призов'ї (Маріуполь). Доп. АН УРСР. 1940. № 3. C. 26-30.

Kuzmenko V.I., 1940. Rare earths in the Petrovo-Hnutonian fluorspar-carbonate vein of the Near-Azovian area (Mariupol). Dopovidi AN URSR, № 3, p. 26-30 (in Ukrainian).

10. Кузьменко В.И. Петрово-Гнутовское месторождение паризита (УкрССР). Сов. геология. 1946. № 12. С. 49-61.

Kuzmenko V.I., 1946. The Petrovo-Hnutonian parasite deposit (UkrSSR). Sovetskaya geologiya, № 12, p. 49-61 (in Russian).

11. Куц В.П. Особенности распределения акцессорных редкоземельных элементов в минералах Петрово-Гнутовского рудопроявления паризита. Докл. АН УССР. Сер. Б. 1971. № 10. С. 892-894.

Kuts V.P., 1971. The special aspects of distribution for rare earth elements in the minerals from the Petrovo- Hnutonian parasite ore occurrence. Dokl. AN USSR. Ser. B, № 10, p. 892-894 (in Russian).

12. Лазаренко Е.К., Лавриненко Л.Ф., Бучинская Н.И. Минералогия Приазовья. Киев: Наук. думка, 1981. 432 с.

Lazarenko Ye.K., LavrinenkoL.F., Buchinskaja N.I., 1981. Minerology of the Near-Azovian area. Kiev: Naukova Dumka, 432 p. (in Russian).

13. Левенштейн М.Л. К вопросу о структуре юго-западной окраины Донецкого бассейна. Изв. АН СССР. Сер. геол. 1959. № 4. С. 91-98.

Levenshtein M.L., 1959. Towards the structure of the south-western margin of the Donets basin. Izvestiya AN SSSR. Seriya geologicheskaya, № 4, p. 91-98 (in Russian).

14. Марченко Е.Я. Об акцессорном сфене из Приазовья. Минерал. сб. Львов. геол. о-ва. 1965. № 19. Вып. 3. С. 378-380.

Marchenko Ye. Ya., 1965. On accessory sphene from the Near-Azovian area. Mineralogicheskiy sbornik Lvovskogo geologicheskogo obschestva, № 19, iss. 3, p. 378-380 (in Russian).

15. Марченко Е.А, Коньков Г.Г., Власенко В.И. О карбонатитовой природе Петрово-Гнутовской дайки Приазовья. Докл. АН УССР. Сер. Б. 1980. № 1. С. 24-27.
Marchenko Ye.Ya., Konkov H.H., Vlasenko V.I., 1980. On carbonatite character of the Petrovo-Hnutovian dyke of the Near-Azovian area. Dokl. AN USSR. Ser. B, № 1, p. 24-27 (in Russian).

16. Марченко Е.Я., Стрекозов С.М. Азовська рудоносна структура докембрію Приазов'я. Мінер. ресурси України. 1999. № 1. С. 34-36.

Marchenko Ye.Ya., Strekozov S.M., 1999. The Azovian ore-bearing structure of the Precambrian of the Near-Azovian area. Mineralny resursy Ukrainy, № 1, p. 34-36 (in Ukrainian).

17. Мельников В.С., Возняк Д.К., Гречановская Е.Е., Гурский Д.С., Кульчицкая А.А., Стрекозов С.Н. Азовское цирконий-редкоземельное месторождение: минералогические и генетические особенности. Минерал. журн. 2000. № 1. С. 42-61.

Melnikov V.S., Vozniak D.K., Hrechanovskaia Ye.Ye., Hursky D.S., Kulchitskya A.A., Strekozov S.N., 2000. The Azovian zirconium-rare earth deposit: Mineralogical and genetic features. Mineralogicheskiy zhurnal, № 1, p. 42-61 (in Russian).

18. Панов Б.С., Коньков Г.Г. Рудные древние свинцы в Восточном Приазовье. Геохимия. 1966. № 7. C. 867-869.

Panov B.S., Kon'kov G.G., 1966. Ore ancient leads in the Eastern Near-Azovian. Geokhimiya, № 7, p. 867-869 (in Russian).

19. Панов Б.С., Стремовский А.М., Бастьен Ж.Л. Редкоземельные и редкие элементы в флюоритах Донбасса и Призовья. Докл. АН УССР. Сер. Б. 1980. № 2. С. 29-32.

Panov B.S., Stremovsky A.M., Bastien Zh.L., 1980. Rare earth and rare elements in fluorspars from the Donbas and Near-Azovian area. Dokl. AN USSR. Ser. B, № 2, p. 29-32 (in Russian).

20. Панов Б.С., Панов Ю.Б. Рудные формации Приазовской редкоземельно-редкометалльной области Украинского щита. Минерал. журн. 2000. № 1. С. 81-85.

Panov B.S., Panov Yu.B., 2000. The ore formations of the Near-Azovian rare earth - rare metal range of the Ukrainian Shield. Mineralogicheskiy zhurnal, № 1, p. 81-85 (in Russian).

21. Пауэлл Дж., Харли Р.М., Форбон Х.В. Изотопный состав стронция и происхождение карбонатитов. В кн.: Карбонатиты. Москва: Мир, 1969. С. 314-325.

Powell J., Harley R.M., Farban H.V., 1969. Strontium isotopic composition and carbonatite genesis. In: Carbonatites. Moskow: Mir, p. 314-325 (in Russian).

22. Стрекозов С.Н., Васильченко В.В., Гурский Д.С. Геологическое строение и характер оруденения Азовского месторождения. Мінер. ресурси України. 1998. № 3. С. 6-9. 
Strekozov S.N., Vasilchenko V.V., Hursky D.S., 1998. Geological structure and character of mineralization from the Azovian deposit. Mineralny resursy Ukrainy, № 3, p. 6-9 (in Russian).

23. Фор Г., Пауэлл Дж. Изотопы стронция в геологии. Москва: Мир, 1974. 213 с.

Faure G., Powell J., 1974. Strontium isotopes in the Geology. Moskow: Mir, 213 p. (in Russian).

24. Хомяков А.П., Семенов Е.И. Гидротермальные месторождения фторкарбонатов редких земель. Москва: Наука, 1971. 133 с.

Khomiakov A.P., Semenov Ye.I., 1971. Hydrothermal deposit for fluorine carbonates of rare earths. Moskow: Nauka, 133 p. (in Russian).

25. Чебаненко И.И., Знаменская Т.А., Шаталов Н.Н. Проявление сдвиговой тектоники в структуре литосферы Украины. В кн.: Сдвиговые тектонические нарушения и их роль в образовании месторождений полезных ископаемых. Москва: Наука, 1991. С. 85-92.

Chebanenko I.I., Znamenskaia T.A., Shatalov N.N., 1991. Manifestation of fault tectonics in the lithosphere structure of Ukraine. In: Fault tectonic dislocations and their role in the mineral deposit formation. Moskow: Nauka, p. 85-92 (in Russian).

26. Шаталов М.М. Деякі структурно-геологічні і вікові особливості дайок ортофірів Павлополь-Октябрського поясу Призов'я. Доп. АН УРСР. Сер. Б. 1980. № 10. С. 34-37.

Shatalov M.M., 1980. Some structural and geological age features for orthophyres dykes from the Pavlopol - Oktiabrs belt of the Near-Azovian area. Dopovidi AN URSR. Ser. B, № 10, p. 34-37 (in Ukrainian).
27. Шаталов М.М. Перша знахідка складнозбудованої дайки в Східному Призов'ї. Доп. $A H$ УРСР. Сер. Б. 1981. № 7. С. 34-37.

Shatalov M.M., 1981. The first finding of compound dyke in the eastern Near-Azovian area. Dopovidi AN URSR. Ser. B, № 7, p. 34-37 (in Ukrainian).

28. Шаталов Н.Н. К вопросу об использовании результатов дешифрирования космо- и аэрофотоснимков при изучении особенностей геологического строения Восточного Приазов'я. Геол. журн. 1982. Т. 42, № 1 (202). С. 68-76.

Shatalov N.N., 1982.Towards the application of satellite and aerial imagery data for the study of geological structure characteristics of the Eastern Near-Azovian area. Geologicheskiy zhurnal, vol. 42, № 1 (202), p. 68-76 (in Russian).

29. Шаталов Н.Н. Дайки Приазовья. Киев: Наук. думка, 1986. 192 с.

Shatalov N.N., 1986. Dykes of the Near-Azovian area. Kiev: Naukova Dumka, 192 p. (in Russian).

30. Щербак Н.П., Артеменко Г.В., Лесная И.М., Пономаренко А.Н., Шумлянский Л.В. Геохронология раннего докембрия Украинского щита. Протерозой. Киев: Наук. думка, 2008. 240 с.

Scherbak N.P., Artemenko H.V., Lesnaia I. M., Ponomarenko A.N, Shumliansky L.V., 2008. The Early Pre-Cambrian Geochronology of the Ukrainian Shield. The Proterozoic. Kiev: Naukova Dumka, 240 p. (in Russian).

Статья поступила 16.06.2014 